\title{
On the Female Images in Feng Menglong's "Three Volumes of Stories"
}

\author{
Xiaoyue Lai \\ Southwest University Press Co., Ltd., Chongqing 400715, China \\ Email: 398412396@qq.com
}

Abstract: Feng Menglong's "Three Volumes of Stories" involves many female images. "Being bought and sold at arbitrarily" was the common destiny of women in that period; "cheating for love" was a new love choice made by women under the influence of the Enlightenment in the late Ming Dynasty; "getting married" can be said to be the resistance of women who were forced to fall in the past dynasties to their fate.

Keywords: Feng Menglong, Three Volumes of Stories, women

Feng Menglong's "Three Volumes of Stories", namely "Stories to Enlighten Men", "Stories to Warn Men" and "Stories to Awaken Men", are extremely rich in content. Scholars, farmers, artisans, merchants, clothing, food, housing and transportation are all included, and they can be called a picture scroll of social life in the late Ming Dynasty. In these stories, there are many women involved, including prostitutes, official ladies, slaves, and ordinary women from the civil class... They together constitute the female group portrait of the late Ming Dynasty. Through these women, we can not only understand the life and social status of women in the late Ming Dynasty, but also get a glimpse of their hidden spiritual world.

\section{Women who were bought and sold arbitrarily}

Being bought and sold arbitrarily can be said to be the common destiny faced by all women in feudal society.

The economic foundation determines the superstructure. In a feudal society centered on patriarchy, women could not become officials through imperial examinations, and they could not show up in business. They could not survive independently. They could only live by relying on men. "Follow the husband after being married; follow the son after the husband dies." This is the truest portrayal of women in that era. Under such circumstances, women have no social status or family status at all. Therefore, at certain specific moments, they become goods, commodities, and tools for others to make profits. The sale of women begins with their native families. For example, in "Cui Daizhao's Enemy", Xiuxiu was sold by her parents to the county king as an female embroiderer; in "Many Women Paid Visit to Liu Yong's Tomb", Zhou Yuexian was forced to pick up guests by her mother; and so on.

In addition to being sold out for poverty or being sold by the government because of family crimes, the sale of women is also hidden in marriage. "Fu Xi's words of making the skins as gifts are not credible. However, the payment of money in the wedding ceremony are all based on goods and money, which is the surviving intention of buying a marriage. The sale of marriage has changed and it has become a matchmaker's marriage. The slave life of women has already begun at this time."[1] It can be said that the ancient marriage system opened the history of women being bought and sold. The bride price at this time, in essence, is the purchase price that measures the worth of women. And marriage is the transfer and delivery of female ownership. In "Jin Lingshi Mei's Maid Paying for Xiu Tong", Jin Lingshi has a maid named Jin Xing. "I loved her as my own daughter, and wanted to get this maid to get rid of her. I waited for another year or two to meet a noble son, marrying him, getting a hundred pounds of silver. Isn't it a pity to be too busy now?" It can be said that Jin Lingshi's psychological activities represented the mentality of most parents who wanted to profit from their daughters' marriage at that time.

The sale of women begins with marriage, but does not end with marriage. In other words, even after marrying someone, women still face the fate of being sold and transferred at any time. For example, in "Mumian Temple Zheng Huchen's Revenge", Hu was sold by his husband Wang Xiaosi and Jia She as a concubine., Wrote a deed to sell his wife, and fell into a cross." ${ }^{2]}$ After Hu was not contained in the main room, after giving birth to the child, he was transferred by Jia Shetuo to the mason as his wife. In "Qiao Yanjie's Concubine Breaks Home", after a weekly inspection in the Jiankang Mansion, his concubine was sold as a concubine by the wife of the main room on the way back to her hometown to support the coffin. In "Ge Lingong Sheng Sends Nong Zhuer", although Nong Zhuer is Ge Lingong's favorite concubine Ji, "day is on his side, night is a private room", but in the end he was still transferred to him by Ge Lingong. Shen Tutai; In "Du Shiniang Sank the Treasure Chest in Anger", Du Shiniang took out one hundred and fifty taels by herself, and asked Li Jia to borrow one hundred and fifty taels, making a total of three hundred taels to redeem himself. As a result, on the way home with Li Jia, Li 
Jia sold Shi Niang to Sun Fu for one thousand taels. It stands to reason that Li Jia is neither a relative of Du Shiniang nor her husband in the legal sense, and he does not have the right to buy and sell Du Shiniang. This can only show that in that era, people subconsciously believed that whoever a woman followed was the person's person, and that person also had all the rights to this woman. Not only did Li Jia sell Shi Niang with peace of mind, but Shi Niang himself, although he hated Li Jia's bad luck, he did not question his right to buy and sell himself. Under the poison of feudal ethics, some women even showed a catering attitude towards their being sold. For example, when Jia She wanted to buy Hu as a concubine, Hu not only did not panic, but also said: "The husband tried to sell his concubine several times, but the concubine refused. The respected officials have pity, and when the husband returns, he respects him. The official said to him that the concubine dared not allow it."

\section{Women who cheated for love}

The Ming Dynasty was one of the dynasties that emphasized the chastity of women and had the most women and martyrs. At the same time, it was also an era when they strongly demanded to break through this bondage. ${ }^{[3]}$ In the middle and late Ming Dynasty, especially after Jiajing, with the continuous expansion of social division of labor and commodity production, the capitalist economy began to sprout, the urban commodity economy became prosperous, and the citizen class continued to grow. The impact of the commodity economy, coupled with the increasing decay of the ruling group, has caused a serious crisis in traditional Confucian culture, especially Cheng-Zhu Neo-Confucianism. Among them, a large number of intellectuals with a strong critical spirit appeared, such as Li Zhi, Huang Zongxi, Wang Yangming, etc. They advocated human nature, human feelings, and sentiments against courtesy. They have greatly influenced people to emancipate their minds and get rid of the shackles of traditional ethics and morals.

This kind of influence is first manifested in the thought of marriage and love and the concept of chastity. In the late Ming Dynasty, under the influence of the Enlightenment trend, young men and women broke through the shackles of the old ideas and the old marriage system to a certain extent, and became more open and tolerant in the thoughts of marriage and love and the concept of chastity. In particular, women who were deeply poisoned by feudal ethics and ethics showed a strong yearning for love and resistance to arranged marriages. "If you don't wait for the orders of your parents, the words of the matchmaker, you can see through the hole and follow the wall, and the parents will be cheap." ${ }^{[4]}$ Loss of virginity before marriage was often fatal for women in ancient times. However, some women in the late Ming Dynasty boldly pursued love in a way of cheating. For example, Liu Suxiang in "Zhang Shunmei Gets a Beautiful Girl at Night" met Zhang Shunmei while playing at night, and loved each other, and Liu Suxiang left behind. One side wins with one heart, and writes "Encounters and meets as usual, which arouses the admiration of the spring heart. Hanging up the colorful lantern is the gateway to your home. At that step, that step, please come and stay at night.", boldly invited Zhang Shunmei to her home to meet; Ms. He in Wu Ya Nei Neighboring Boats" saw this figure in Wu Ya Nei, unconsciously moved selfishly, and thought: "This Ya Nei is really charming and elegant. If I marry such a husband, I will be satisfied." Take the initiative to deliver the letter and invite $\mathrm{Wu}$ Yanei to meet on the boat at night; Wang Jiaoluan and Zhou Tingzhang in "A Hundred Years of Wang Jiaoluan" fall in love with Zhou Tingzhang, and finally become a pillow love; Li Yingying and Zhang Hao in "Su Xiang Ting Zhang Hao Meet Yingying" In love, Ling Hui Ji sent a small card to Zhang Sheng, saying, "Being under the wall, I want to see you over the wall"...

These women dare to break through the shackles of feudal ethics and morals when they meet the people they like, take the initiative to pursue them, and recommend themselves. However, it is worth mentioning that these women's cheating behavior is based on love. It is a combination of spirit and flesh. It is essentially different from cheating for pure sensuality. Their ultimate desire is to marry. For the beloved, instead of becoming a legal couple. Cheating is not only the result of the burning fire of love, but also the comfort after marriage is blocked, and to a certain extent it can be regarded as a means for women to retain and reward their lover. After Liu Suxiang and Zhang Shunmei had an affair, in order to be a long-term husband and wife, the two chose to elope, but unfortunately they were separated. Liu Suxiang missed Zhang Shunmei and had eaten and recited Buddha at Daci Temple for three years. When facing Zhou Tingzhang's begging for love, Jiao Luan was initially resisted, she The righteous words said strictly: "The concubine Ben Zhenhime, the king is not a dangling son. Only because of talent and appearance, so love and pity each other. Concubine is a private king, and finally keeps the monarch's festival; if you abandon your concubine, will you not lose the concubine's sincerity? She must swear to Mingshen, swear to be with the white head, if still fornicating, there will be death." Zhou Tingzhang swore and wrote the contract marriage letter, after worshipping the world, Jiao Luan only agreed to Zhou Sheng's courtship. In "Su Xiang Ting Zhang Hao Meets Yingying", in the face of Zhang Sheng's confession, Yingying boldly confessed her heart, but she asked Zhang Sheng to ask for marriage first and establish the relationship between the two in the form of marriage: "Youth Mu Junqing Virtue, the family has strict marriages, rituals and laws, and no reason to meet with the monarch. Today the monarch still does not 
marry, and the concubine also hangs down. Among the sacrificial offerings, we serve aunt Weng, harmonious relatives, and are good for both sexes, without the blemish of the seven, this concubine's prime heart."

Women chose to "beyond the wall and follow the wall" for love. Due to the budding of capitalism in the late Ming Dynasty, people's ideas also tended to be open to a certain extent. A lot of tolerance and understanding. In "Qiao Taishou Chaotic Point of Mandarin Duck", Sun Yulang and Hui Niang committed adultery, and Qiao Taishou thought that they fell in love with each other, and finally sentenced them to marrying. In "Jiang Xing Ge Reunion with Pearl Shirt", San Qiao'er went out for business with her husband Jiang Xing Ge. When Chen Dalang was seduced by Chen Dalang, he developed a relationship with him; Jiang Xingge, as a husband, was very angry after discovering his wife's adultery, but he also reflected on himself: "How affectionate the husband and wife were at the time, because I was greedy for petty gains and left him. Juvenile widowhood, made this ugly..." From these examples, we can see the changes in people's outlook on chastity in the late Ming Dynasty.

\section{Women who got married}

In the middle and late Ming Dynasty, the sprouts of capitalism had already appeared in the southeast coastal area, and the urban economy was further prosperous. The prosperity of the urban economy has further promoted the development of the prostitute industry. The Ming Dynasty Zhaozhe once said: "Nowadays, prostitutes are all over the world, and the metropolis has thousands of people. Other poor prefectures and remote towns are in existence." Lin Xiyuan also said in Jiajing, "Today is the same as the two capitals." Nine Streets (prostitutes) amounted to tens of thousands." In terms of thinking, early Confucianism emphasized the lack of desire. By the Song and Ming dynasties, Confucianism was based on Cheng-Zhu Neo-Confucianism as the mainstream, completely denying people's desires, and advocating "save nature and destroy human desires." , Regarding sexual desire as a scourge, and adopting compulsory "blocking" and "prevention" methods, rather than conforming to human nature and easing it. ${ }^{[5]}$ In the middle and late Ming Dynasty, heretical thoughts represented by Li Zhi and others gradually emerged, emphasizing human desires and affirming human value. Under the impact of this kind of thought, human desire is like a flood of dyke breaking, and people indulge in sensuality. It is also late. One of the important reasons why brothels are blooming everywhere.

Although the prostitution industry has developed and prospered, since ancient times, the social status of prostitutes has been extremely low. They are regarded as inferior and used as playthings. Young, beautiful and fashionable, there are swingers who are chasing and laughing. Therefore, many women who were forced to fall into the dust, with good talents and appearance, secretly determined to be good, fantasizing about finding a congenial person to spend the rest of their life together. The objects that these women seek to entrust to life are often literati. The reasons for this are, first of all, since ancient times, literati have had the tradition of prostitutes. They were frequent visitors of the fireworks and willow lanes and the people most contacted by prostitutes. Secondly, the society at that time was divided into three, six or nine occupations. "Agriculture, industry and commerce" ranks the top scholars. Scholars have status and talent, and can chant poems and make fus. This is undoubtedly more attractive to the elegant prostitutes who are proficient in all kinds of piano, chess, calligraphy and painting. Again, the literati are undoubtedly the most rebellious group of people in that era. They dared to break through the worldly perspective, not to regard prostitutes as inferior, but to appreciate the talents of prostitutes, sympathize with their misfortunes, and treat them with equality. In "All Names Ji Chunfeng Hanging Liu Qi", Liu Yong respects the personality of prostitutes, appreciates their talents, writes free lyrics for them, and talks with them heartily. When Zhou Yuexian, a prostitute from Yuhang, was persecuted by Liu Eryuan, he offered to help Zhou Yuexian out of her nationality, so that she married his lover Huang Xiucai.

In his early years, Feng Menglong was not the first in the imperial examination. When he was discouraged, he often lingered in the Qinlou Chuguan, and fell in love with the famous geisha Hou Huiqing at that time. Feng Menglong fully appreciates the talented and virtuous prostitutes, as he said, "'Women with lofty ideals are better than men.' And like women, only prostitutes are the cheapest, and there are many outstanding ones." In his "Three Volumes of Stories", he portrayed many talented and beautiful firework women. These women are either loyal, such as Guan Panpan and Yutangchun; or courageous, such as Zhao Chuner and Xin Yaoqin; or unyielding, such as Zhao Shiniang, etc. And these excellent women finally chose to leave the fireworks field in a good way. It is worth noting that in the late Ming Dynasty, with the development of the commodity economy, the status of merchants increased rapidly, and merchants became one of the targets of prostitutes. For example, in "Oiran Exclusively by the Oil Seller", the Oiran lady finally married the oil seller Qin Zhong.

\section{Summary}

The images of women in the "Three Volumes of Stories" are extremely rich. Among them are the "matchmaking" Ma 
Liupo, the old bustard who loves money as life, the virgin who is determined to keep the rules, and the indulgent nuns, widows, and recipients. Humiliated, revengeful women, etc. This article mainly narrates the girls who cheat for love and the prostitutes who are good for love, and they are also the objects of Feng Menglong's intense color and effort to express. From these characters, we can see the general fate of women in that era and their struggle against their own fate.

\section{References}

[1] Chen Dongyuan. Ancient Chinese Women's Life History [M]. Beijing: The Commercial Press, 2015: 20.

[2] Feng Menglong. Yu Shimingyan [M]. Changsha: Yuelu Publishing House, 1989: 187.

[3] Wang Jianke. Research on Family Narrative Literature of Yuan and Ming Dynasties [D]. Doctoral Dissertation of Shaanxi Normal University.

[4] Complete translation of the Four Books and Five Classics [M]. Tao Xinhua, translated. Beijing: Thread-bound Bookstore, 2016: 197.

[5] Xu Lin. Research on Jiangnan Scholars' Social Communication in the Middle and Late Ming Dynasty[M]. Shanghai: Shanghai Ancient Books Publishing House, 2006: 130. 